\title{
Exploring the Impact of Communication on Employee Performance
}

\author{
Ong Choon Hee, Delanie Ang Hui Qin, Tan Owee Kowang, Maizaitulaidawati Md Husin, \\ Lim Lee Ping
}

\begin{abstract}
This study aims to examine types of communication such as horizontal communication, downward communication and upward communication that impact employee performance in a property development company in Malaysia. Survey questionnaire approach was applied to collect data in this study. A total of 120 respondents participated in this research. The results indicated that downward communication $(D C)$ and horizontal communication $(\mathrm{HC})$ have significant positive impacts towards employee performance. The research finding is able to provide insights and important information to the property development firms to better understand the importance of communication among employees in enhancing employee performance. For this to happen, management may focus on the development of soft skills to increase the ability to express and communicate among the employees. Management should organize more activities such as inter-departmental meetings to create quality bonding among superiors and subordinates. Proper training and development plan should be established to realize effective communication in the organization.
\end{abstract}

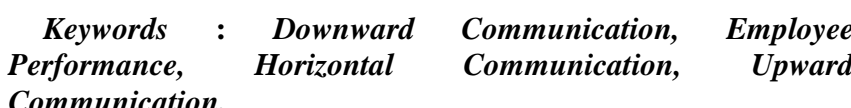

\section{INTRODUCTION}

Human use communication as a channel to interact with each other in day to day life [1]. Good communication is a necessary tool in achieving high quality of performance and maintaining strong working relationships within the organization. The trust among employees can be build up if everyone is spending time into delivering clear communication. Effective communication boosts employee productivity and binds employees together. It builds team and increases employee performance and at the same time it reduces employee turnover in the organization. However, weak communication in the organization will lead to loss of confidence and ineffective operation [2]. Organizations that are deficient in their communication do not achieve the same performance as those that communicate well [3]. Researchers such as Bakar, Walters and Halim [4] had expressed the

Revised Manuscript Received on October15, 2019

* Correspondence Author

Ong Choon Hee*, Azman Hashim International Business School, Universiti Teknologi Malaysia, Johor Bahru, Malaysia. Email: ongchoonhee@gmail.com

Delanie Ang Hui Qin, Azman Hashim International Business School, Universiti Teknologi Malaysia, Johor Bahru, Malaysia.

Tan Owee Kowang, Azman Hashim International Business School, Universiti Teknologi Malaysia, Johor Bahru, Malaysia.

Maizailtulaidawati Md Husin, Azman Hashim International Business School, Universiti Teknologi Malaysia, Johor Bahru, Malaysia.

Lim Lee Ping, Azman Hashim International Business School, Universiti Teknologi Malaysia, Johor Bahru, Malaysia. importance of communication in organizations. Yet, they found that the importance of communication among employees has often being neglected in the organization. Hence, this study intends to bridge the gap by raising the below research questions:

1. What is the relationship between horizontal communication and employee performance?

2. What is the relationship between upward communication and employee performance?

3. What is the relationship between downward communication and employee performance?

\section{LITERATURE REVIEW AND HYPOTHESIS DEVELOPMENT}

\section{A. Employee Performance}

Employee performance is a behavior of an employee when he or she is performing a job or task [5]. It is something or outcome produced by the employees in the organization [6]. Employee performance involves the achievement of each employee in accordance with the organization's regulations, requirements and expectation. Employee performance is the result of ability, effort and perception of task from the employees [7], [8]. It helps to enhance the productivity of the organization by improving efficiency and effectiveness of the tasks. Excellent employee performance creates outcomes like high quality and high productivity among employees in the organization [9]. The morale and energy of the employees will be boosted when people surrounding them are doing their job effectively [5]. The way on how organization communicates with its employee reflects the performance of its employees. Effective communication allows employees in an organization to become productive and efficient [10].

\section{B. Horizontal Communication}

Horizontal Communication is the employee communication across the same level in the organization [1] The message is transmitted along the similar level within an organization. Horizontal communication directly shares information, solves problem and works together efficiently [11]. It usually produces a higher quality of information exchange as it occurs directly between employees working in the same level [12]. Horizontal communication coordinates the activities of different departments in the organization [13] It helps in developing stronger relationship for employees in both similar department and different departments. 


\section{Exploring the Impact of Communication on Employee Performance}

Horizontal communication also enhances the involvement of employees in the organization [12]. The availability to express views and opinions improves employee performance. Effective horizontal communication decreases misunderstanding and conflict in the organization and increases the network and assists employees in performing their jobs [13]. This makes the employees happier and more successful in the organization. Hence, it is hypothesized that:

\section{H1: Horizontal communication positively influences} employee performance.

\section{Upward Communication}

Upward communication is a communication from subordinates to their superiors in the organization [1]. The message is transmitted from bottom to top along the hierarchy. This usually happens when subordinates request for opinions from their superiors. It is a type of communications that triggers decision from the top management [14]. Upward communication promotes cooperation and gains support from the superiors. Upward communication enables employees express their feelings about jobs and procedures in the organization [15]. Apart from that, upward communication also reflects the ability of employees in performing their jobs [14]. For example, subordinates should know the expectations of their superiors and discuss with them in relation to job interest and future career development. In this case, superiors and subordinates could work cohesively to produce better results and attain excellent performance. Therefore, it is hypothesized that:

H2: Upward communication positively influences employee performance.

\section{Downward Communication}

Downward communication is a communication from superiors to subordinates in the organization [1]. The message is transmitted from top to bottom along the hierarchy. Superiors normally share information with their lower level employees [16]. This would assure that employees understand the organization goals clearly [17]. The more information is shared the more productive the employee is expected [10]. Effective downward communication improves leadership communication by sharing regular updates in the organization [11]. Superiors who provide subordinates with useful and accurate information could reduce uncertainties among them [16]. This makes the employees to understand the reasons for management decision [16]. In addition, downward communication transfers work-related information to the subordinates effectively and ensure employees work for the best interest of the organization. Superior could also use downward communication to provide feedback on employee performance so that individuals are able to improve it from time to time. Therefore, it is hypothesized that:

H3: Downward communication positively influences employee performance.

\section{METHODOLOGY}

\section{A. Population and Sample}

The total population of this study consists of 120 employees in a property development company. According to Krejcie and Morgan [18], the minimum sample size is 92 for a population of 120 . However, this study selects all the population as samples as it is possible to reach each respondent of the population.

\section{B. Measures}

The measures of employee performance (12 items) were adapted from the study of Abelsen et al. [19]. The items of horizontal communication (6 items) were adapted from Bakar, Walters and Halim [4] while the items for upward communication (6 items) were adapted from Michael [20]. Measures for downward communication (6 items) were adapted from Abelsen et al. [19]. Likert scale was used to measure the level of agreement for all the study variables. The scale was anchored by 1 (Strongly Disagree), 2 (Disagree), 3 (Neutral), 4 (Agree) and 5 (Strongly Agree).

\section{Data Collection Procedure}

Online questionnaires were used in this research because it is an efficient way to collect data from the respondents. The questionnaire is set to be completed by the respondents in 10 minutes. Online questionnaires were distributed to the respondents via emails and mobile applications. Statistical Package for Social Sciences (SPSS) software was used to analyze the data obtained.

\section{RESULTS}

\section{A. Profile of the Respondents}

Among the 120 respondents, 42 were males and 78 were females. Majority of the respondents were aged between 26 to 35 years old which accounted for $54.2 \%$ of all the respondents. In terms of marital status, 95 of the respondents were single $(79.2 \%)$ and $25(20.8 \%)$ were married. In the category of education background, most of the respondents $(104,86.7 \%)$ were bachelor's degree holders.

\section{B. Factor Analysis and Reliability Test}

Factor Analysis was conducted by employing Principal Component Analysis (PCA) to assess validity of the study variables. Based on the results obtained from the Principal Component Analysis (PCA), one of the independent variables, upward communication has been eliminated. The elimination of upward communication was due to cross loadings with other study variables. Table 1 shows the results of factor analysis for the independent variables (i.e. downward communication and horizontal communication). Table 2 indicates a single factor for the dependent variable (i.e. employee performance). All the variables were deemed reliable as they had achieved the alpha values beyond 0.70 as suggested by Tavakol and Dennick [21]. 
Table 1. Factor Analysis for the Independent Variables

\begin{tabular}{|c|c|c|c|}
\hline \multirow{2}{*}{ Item } & \multirow{2}{*}{ Description } & \multicolumn{2}{|c|}{ Factor Loading } \\
\hline & & 1 & 2 \\
\hline $\mathrm{DC} 1$ & $\begin{array}{l}\text { My superior provides } \\
\text { sufficient amounts of useful } \\
\text { information that I understand. }\end{array}$ & 0.931 & \\
\hline DC2 & $\begin{array}{l}\text { My superior share and } \\
\text { respond to information in a } \\
\text { timely manner. }\end{array}$ & 0.924 & \\
\hline DC3 & $\begin{array}{l}\text { My superior actively listen to } \\
\text { my viewpoints. }\end{array}$ & 0.936 & \\
\hline DC4 & $\begin{array}{l}\text { My superior always speaks } \\
\text { politely and this motivates me } \\
\text { to model him/her. }\end{array}$ & 0.940 & \\
\hline DC5 & $\begin{array}{l}\text { I know what I am expected to } \\
\text { achieve when I am given a task } \\
\text { at work. }\end{array}$ & 0.927 & \\
\hline DC6 & $\begin{array}{l}\text { My superior maintains } \\
\text { essential information flows to } \\
\text { me. }\end{array}$ & 0.950 & \\
\hline $\mathrm{HC} 1$ & $\begin{array}{l}\text { I always avoid using harsh } \\
\text { language when communicate } \\
\text { with colleagues. }\end{array}$ & & 0.685 \\
\hline $\mathrm{HC} 2$ & $\begin{array}{l}\text { I use polite language to advise } \\
\text { my colleagues. }\end{array}$ & & 0.886 \\
\hline $\mathrm{HC} 3$ & $\begin{array}{l}\text { I use appropriate language to } \\
\text { address others. }\end{array}$ & & 0.869 \\
\hline $\mathrm{HC} 4$ & $\begin{array}{l}\text { I try to interact with } \\
\text { colleagues nicely at work. }\end{array}$ & & 0.858 \\
\hline HC5 & $\begin{array}{lll}\text { I always respect my } \\
\text { colleagues' views. }\end{array}$ & & 0.792 \\
\hline HC6 & $\begin{array}{l}\text { I helps someone without being } \\
\text { asked. }\end{array}$ & & 0.725 \\
\hline \multicolumn{2}{|c|}{ Eigenvalue } & 7.109 & 2.617 \\
\hline \multicolumn{2}{|c|}{ Percentage of Variance Explained (\%) } & 58.495 & 21.805 \\
\hline \multicolumn{2}{|c|}{ Cumulative Percentage $(\%)$} & 58.495 & 80.300 \\
\hline \multicolumn{2}{|c|}{$\begin{array}{l}\text { Reliability Coefficient } \quad \text { (Cronbach } \\
\text { Alpha) }\end{array}$} & 0.983 & 0.897 \\
\hline
\end{tabular}

Table 2. Factor Analysis for Employee Performance

\begin{tabular}{|c|l|c|}
\hline Item & \multicolumn{1}{|c|}{ Description } & $\begin{array}{c}\text { Factor } \\
\text { Loading }\end{array}$ \\
\cline { 2 - 3 } EP1 & $\begin{array}{l}\text { I receive meaningful recognition for } \\
\text { work well done. }\end{array}$ & 1 \\
\hline EP2 & $\begin{array}{l}\text { I receive useful feedback from } \\
\text { superior on my job performance. }\end{array}$ & 0.891 \\
\hline EP3 & $\begin{array}{l}\text { My work has made contribution to the } \\
\text { good of the organization would please } \\
\text { me. }\end{array}$ & 0.896 \\
\hline EP4 & $\begin{array}{l}\text { I like to feel that I am making some } \\
\text { contribution not for myself but for the } \\
\text { organization as well. }\end{array}$ & 0.882 \\
\hline EP5 & $\begin{array}{l}\text { I persist in overcoming obstacles to } \\
\text { complete a task. }\end{array}$ & 0.850 \\
\hline EP6 & $\begin{array}{l}\text { I meet the formal performance } \\
\text { requirements of the job. }\end{array}$ & 0.836 \\
\hline
\end{tabular}

\begin{tabular}{|c|l|c|}
\hline EP7 & $\begin{array}{l}\text { I put in extra hours to get work done } \\
\text { on time. }\end{array}$ & 0.796 \\
\hline EP8 & I am enthusiasm in performing my job. & 0.924 \\
\hline EP9 & I am initiative in doing my work. & 0.909 \\
\hline EP10 & $\begin{array}{l}\text { My work hard leads to good } \\
\text { performance. }\end{array}$ & 0.887 \\
\hline EP11 & $\begin{array}{l}\text { My work hard leads to high } \\
\text { productivity. }\end{array}$ & 0.892 \\
\hline EP12 & $\begin{array}{l}\text { My work hard leads to doing my job } \\
\text { well. }\end{array}$ & 0.884 \\
\hline Eigenvalue & 9.253 \\
\hline Percentage of Variance Explained (\%) & 77.106 \\
\hline Cumulative Percentage (\%) & 77.106 \\
\hline Reliability Coefficient (Cronbach Alpha) & 0.972 \\
\hline
\end{tabular}

Note. $\mathrm{KMO}=0.923$, Bartlett's test of Sphericity: Approx.Chi-Square $=1930.637, \mathrm{p}<0.001$.

\section{Correlation Analysis}

The results tabulated in Table 3 show that downward communication $(\mathrm{r}=0.772, \mathrm{p}<0.01)$ has the strongest correlation with employee performance, followed by horizontal communication $(\mathrm{r}=0.523, \mathrm{p}<0.01)$. The results indicate that there are positive correlations between employee performance and the independent variables.

Table 3. Correlation between the Independent Variables and Employee Performance

\begin{tabular}{|c|c|c|c|}
\hline & (HC) & (DC) & (EP) \\
\hline $\begin{array}{c}\text { Horizontal } \\
\text { Communication (HC) }\end{array}$ & 1 & 1 & \\
\hline $\begin{array}{c}\text { Downward } \\
\text { Communication (DC) }\end{array}$ & $0.439 * *$ & $0.772 * *$ & 1 \\
\hline $\begin{array}{c}\text { Employee Performance } \\
\text { (EP) }\end{array}$ & $0.523 * *$ & 0.772 . \\
\hline
\end{tabular}

**Correlation is significant at the 0.01 level (2-tailed).

\section{Multiple Regression Analysis}

Table 4 shows the multiple linear regression analysis among the independent variables and employee performance. The results indicate that 63.9 percent $(\mathrm{R} 2=0.639)$ of the variance of employee performance can be explained by the two independent variables. The analysis shows that all independent variables have a significant positive relationship with employee performance. Downward communication $(\beta=0.672, \quad p<0.001)$ has the strongest relationship with employee performance, followed by horizontal communication $(\beta=0.229, \mathrm{p}<0.001)$. Therefore, hypothesis $\mathrm{H} 1$ and $\mathrm{H} 2$ are accepted.

Table 4. Multiple Regression Analysis among the Independent Variables and Employee Performance

\begin{tabular}{|c|c|c|c|c|c|}
\hline \multirow[t]{2}{*}{ IVs } & \multicolumn{4}{|c|}{ Employee Performance (DV) } & \multirow[t]{2}{*}{ Result } \\
\hline & $\begin{array}{c}\text { Beta, } \\
\beta\end{array}$ & Sig. & B & $\begin{array}{l}\text { Std. } \\
\text { Error }\end{array}$ & \\
\hline $\begin{array}{l}\text { Horizontal } \\
\text { Communic } \\
\text { ation }(\mathrm{HC})\end{array}$ & $\begin{array}{c}0.229 \\
* * *\end{array}$ & 0.000 & 0.298 & 0.081 & $\begin{array}{c}\mathrm{H} 1 \\
\text { Accepted }\end{array}$ \\
\hline $\begin{array}{l}\text { Downward } \\
\text { Communic } \\
\text { ation (DC) }\end{array}$ & $\begin{array}{c}0.672 \\
* * *\end{array}$ & 0.000 & 0.449 & & \\
\hline
\end{tabular}


Exploring the Impact of Communication on Employee Performance

\begin{tabular}{|l|c|}
\hline F value & 103.380 \\
\hline R Square & 0.639 \\
\hline
\end{tabular}

***Significant at the 0.001 level.

\section{DISCUSSION}

The findings showed that there is a significant positive relationship between horizontal communication and employee performance $(\beta=0.229, \mathrm{p}<0.001)$. This implies that the higher the horizontal communication, the higher the employee performance. This finding is supported by Ince and Gil [15], who exerted that in increasing horizontal communication among employees, it would affect employee performance in a positive way. Other researchers such as Kibe [22], Sgobbi and Cainarca [23] also postulated that there is a positive relationship between horizontal communication and employee performance. The researchers found that horizontal communication encourages learning and decision making at the lower level of hierarchy in the organization. It enables a higher degree of teamwork among staffs and reflects higher performance in their works. As reported in the multiple regression analysis results, downward communication was found to be significantly related to employee performance $(\beta=0.672, p<0.001)$. This finding is supported by Okyere [1], who postulated that there is a positive significant relationship between downward communication and employee performance. Downward communication is expected to share information between superiors and subordinates. Frequent downward communication can reduce unnecessary burden and improve employee performance in the organization. Other researchers such as Abdullah and Hui [24], found that downward communication inspires employees with the way the information is delivered and received. Junior staffs usually receive information about their works from senior staffs in the organization. Hence, downward communication enables junior staffs to understand expectations from the senior leaders in performing their tasks [10].

\section{CONCLUSION}

The findings of this study provide empirical evidence to the management to ensure effective downward and horizontal communication take place in the organization. For this to happen, management may focus on the development of soft skills to increase the ability to express and communicate among the employees. Management may organize more activities such as inter-departmental meetings to create quality bonding among superiors and subordinates. Proper training and development plan should be established to realize effective communication in the organization [25].

\section{ACKNOWLEDGMENT}

The authors thank the Ministry of Education Malaysia, Universiti Teknologi Malaysia (GUP Tier 2: 15J99) and Azman Hashim International Business School for providing financial support to publish this paper.

\section{REFERENCES}

1. Okyere, Y. O., "The impact of effective communication on organizational performance," The International Journal of Social Sciences and Humanities Invention, vol. 3(3), pp. 1904-1914, 2011.
2. Bücker, J. L. E., Furrer, O., Poutsma, E., Buyens, D., “The impact of cultural intelligence on communication effectiveness, job satisfaction and anxiety for Chinese host country managers working for foreign multinationals," International Journal of Human Resource Management, vol. 25(14), pp. 2068-2087, 2014.

3. Thomaz, J. C., "Identification, reputation, and performance: Communication mediation," Journal of Latin American Business Review, vol. 11(2), pp. 171-197, 2010.

4. Bakar, H. A., Walters, T., Halim, H., "Measuring communication styles in the Malaysian workplace: Instrument development and validation," Journal of Intercultural Communication Research, vol. 18(3), pp. 37-41, 2014.

5. El-Zeiny, R. M. A., "The interior design of workplace and its impact on employees' performance: A case study of the private sector corporations in Egypt," Procedia - Social and Behavioral Sciences, vol. 35, pp. 746-756, 2012. Available: https://doi.org/10.1016/j.sbspro.2012.02.145.

6. Adewale, A. J., Abodunde, S. M., Folorunso, O. O., "Exploring the effect of organizational commitment dimensions on employee performance: An empirical evidence from academic staff of oyo state owned tertiary institutions, Nigeria," International Journal of Academic Research in Business and Social Sciences, vol. 4(8), pp. 275-286, 2014.

7. Hee, O.C., Cheng, T.Y., Yaw, C.C., Gee, W.V., Kamaludin, S.M., Prabhagaran, J.R., "The Influence of Human Resource Management Practices on Career Satisfaction: Evidence from Malaysia," International Review of Management and Marketing, vol. 6(3), pp. 517-521, 2016.

8. Ping, L.L., Ahmad, U.N.U., Hee, O.C., "Personality traits and customer-oriented behavior of the Malaysian nurses," International Business Management, vol. 10(13), pp. 2579-2584, 2016.

9. Hee, O.C., Ibrahim, R., Kowang, T.O., Fei, G.C., "Employee engagement as a mediator between transformational leadership and employee performance," Asian Journal of Scientific Research, vol. 11(3), pp. 441-448, 2018.

10. Verghese, A. K., "Internal communication: Practices and implications," Journal of Indian Management, vol. 103-113, 2017.

11. Shonubi, A. O., Akintaro, A. A., "The impact of effective communication on organizational performance," The International Journal of Social Science and Humanities Invention, vol. 3(3), pp. 1904-1914, 2016

12. Mutuku, C. K., Mathooko, and P., "Effects of organizational communication on employee motivation: A case study of Nokia Siemens networks Kenya," International Academic Journal of Information Sciences and Project Management, vol. 1(3), pp. 28-62, 2014.

13. Ramdhani, A., Ramdhani, M. A., Ainisyifa, H., "Model conceptual framework of corporate culture influenced on employee's commitment to organization," Journal of Business Management, vol. 11(3), pp. 826-830, 2017.

14. Giri, V. N., Kumar, B. P., "Assessing the impact of organizational communication on job satisfaction and job performance," Journal of Psychological Studies, vol. 55(2), pp. 137-142, 2010.

15. Ince, M., Gul, H., "The role of the organizational communication on employees' perception of justice: A sample of public institution from Turkey," Journal of Social Sciences, vol. 21(1), pp. 106-124, 2011.

16. Hartog, D. N. D., Boon, C., Verburg, R. M., Croon, M.A., "HRM, communication, satisfaction, and perceived performance: A cross-level test," Journal of Management, vol. 39(6), pp. 1637-1665, 2012.

17. Ajala, E.M., "The influence of workplace environment on workers' welfare, performance and productivity," Journal of the African Educational Research Network, vol. 12(1), pp. 1-12, 2012.

18. Krejcie, R. V., Morgan, D. W., "Determining sample size for research activities," Journal of Educational and Psychological Measurement, vol. 30, pp. 607-610, 1970.

19. Abelsen, B., Gaski, M., Brandstorp, H., "HRM, communication, satisfaction, and perceived performance: A cross-level test," Journal of Management, vol. 39(6), pp. 1637-1665, 2015. 
20. Michael, D., "Supportive supervisor communication as an intervening influence in the relationship between LMX and employee job satisfaction, turnover intention, and performance," Journal of Behavioral Studies in Business, vol. 4, pp. 1-29, 2014.

21. Tavakol, M., Dennick, R., "Making Sense of Cronbach's Alpha," International Journal of Medical Education, vol. 2, pp. 53-55, 2011. Available: https://doi.org/10.5116/ijme.4dfb.8dfd

22. Kibe, C. W., "Effects of communication strategies on organizational performance: A case study of Kenya ports authority," Journal of Business and Management, vol. 6(11), pp. 6-11, 2014.

23. Sgobbi, F., Cainarca, G. C., "High-Performance work practices and core employee wages: Evidence from Italian manufacturing plants," 2015. Available: https://doi.org/10.1177/0019793914564967.

24. Abdullah, Z., Hui, J., "The relationship between communication satisfaction and teachers' job satisfaction in the Malaysian primary school," Journal of Academic Research in Human Resource, vol. 2(2), pp. 58-71, 2014.

25. Long, C.S., Kowang, T.O., Chin, T, A., Hee, O.C., "Improving organizational performance through training function: A review," International Business Management, vol. 10(4), pp. 475-478, 2016. 